\title{
Perancangan Aplikasi Sistem Informasi Sumsel Tourism Berbasis Android
}

\author{
Febby Ayu Permatasari, Ali Nurdin, Jon Endri \\ Politeknik Negeri Sriwijaya \\ Jl. Srijaya Negara Bukit Besar, Palembang \\ Febbyayup28@gmail.com
}

\begin{abstract}
The increase in the number of tourists to South Sumatra can be seen from the interest of visitors who come to the area for tourist destinations. The tourists from outside of South Sumatra who have visited this province for the first time will have difficulty accessing detailed information on tourist place and lodging. So, South Sumatra should be able to develop facilities regarding tourist directions to facilitate tourists. The purpose of this research presents an application to help users find information about tourist place and lodging then make users easier to book tourist place. The development of application made using the waterfall method and the Java, PHP, XML programming language with Android Studio 181.5 software. Then the concept used is the Unified Modeling Language (UML) with Activity Diagrams. The results of this research are android-based by online application that can display information in the form of profiles, contacts, budget, routes to the location of tourist places and lodging places then make the tourist easier to book tourist places.
\end{abstract}

Keywords: Information System, Tourism, Android, South Sumatera, Java

\begin{abstract}
Abstrak
Peningkatan jumlah wisatawan ke provinsi Sumatera Selatan terlihat dari minat pengunjung yang datang ke daerah untuk tujuan wisata. Para wisatawan dari luar Sumsel yang baru pertama kali mengunjungi provinsi ini akan kesulitan mengakses detail informasi tempat wisata dan penginapan. Maka, seharusnya Sumatera Selatan dapat mengembangkan fasilitas mengenai arahan objek wisata untuk memudahkan wisatawan. Tujuan dari penelitian ini menyajikan aplikasi guna membantu user mencari informasi tentang tempat wisata dan penginapan serta memudahkan user memesan tempat wisata. Adapun pengembangan aplikasi yang dibuat menggunakan metode waterfall dan bahasa pemrograman Java, PHP, XML dengan software Android Studio 181.5. Lalu konsep yang digunakan Unified Modelling Language (UML) dengan Activity Diagram. Hasil dari penelitian ini yaitu aplikasi online berbasis android yang dapat menampilkan informasi berupa profil, kontak, budget, rute menuju ke lokasi tempat wisata dan tempat penginapan serta memudahkan wisatawan memesan tempat wisata.
\end{abstract}

Kata kunci: Sistem Informasi, Pariwisata, Android, Sumatera Selatan, Java

\section{PENDAHULUAN}

Perkembangan provinsi Sumatera Selatan cukup pesat dilihat dari kunjungan para wisatawan yang datang semakin hari bertambah. Menurut Yos Rudiansya Kepala BPS Sumsel, jumlah wisatawan mancanegara apabila dibandingkan tahun 2017 terjadi peningkatan di tahun 2018 dengan total kunjungan wisatawan 
mancanegara sebesar 17,05 persen [1]. Melihat banyaknya event nasional dan internasional di kota besar provinsi Sumatera Selatan khususnya Palembang, sebaiknya promosi wisata di Sumatera Selatan harus ada peningkatan. Hal ini dapat diatasi dengan memanfaatkan kemajuan teknologi berupa Sistem Informasi. Oleh karena itu, dibutuhkan sebuah sistem berbasis android yang mampu memberikan informasi pariwisata kepada wisatawan. Diharapkan melalui penggunaan aplikasi ini wisatawan mendapatkan informasi dengan cepat dan realtime [2].

Adapun destinasi wisata di Dinas Kebudayaan Pariwisata Kota Palembang dibagi menjadi 2 Destinasi antara lain : Wisata Alam, Wisata Sejarah Budaya dan Wisata Minat Khusus [3]. Menurut penelitian sebelumnya, sistem informasi pariwisata dibuat dalam bentuk web dan lokasinya hanya di kota Palembang saja. Penyajian informasi dalam bentuk web kurang fleksibel dan kurang akurat dalam kelengkapan informasi tempat wisata serta menampilkan titik koordinat peta [4]. Maka dari itu, dibuat Aplikasi Sistem Informasi masing-masing daerah pada Provinsi Sumatera Selatan berbasis android. Sistem android ini mudah dibangun, free, dan dapat mengerjakan beberapa pekerjaan sekaligus dalam waktu yang bersamaan. Berdasarkan uraian diatas, Penulis merasa diperlukannya untuk membangun aplikasi sistem informasi objek wisata dengan judul "Rancang Bangun Aplikasi Sistem Informasi Sumsel Tourism Berbasis Android” untuk memberikan informasi secara lebih lengkap dan akurat untuk para wisatawan agar dapat dikenal semua lapisan masyarakat di seluruh Indonesia.

\section{METODOLOGI PENELITIAN}

\subsection{Metode Penelitian}

Pada penelitian ini bahasa pemrograman Java, PHP, metode yang diterapkan yaitu metode waterfall. Metode waterfall merupakan model pengembangan sistem informasi yang sistematik dan sekuensial [5]. Metode ini memiliki tahapantahapan sebagai berikut:

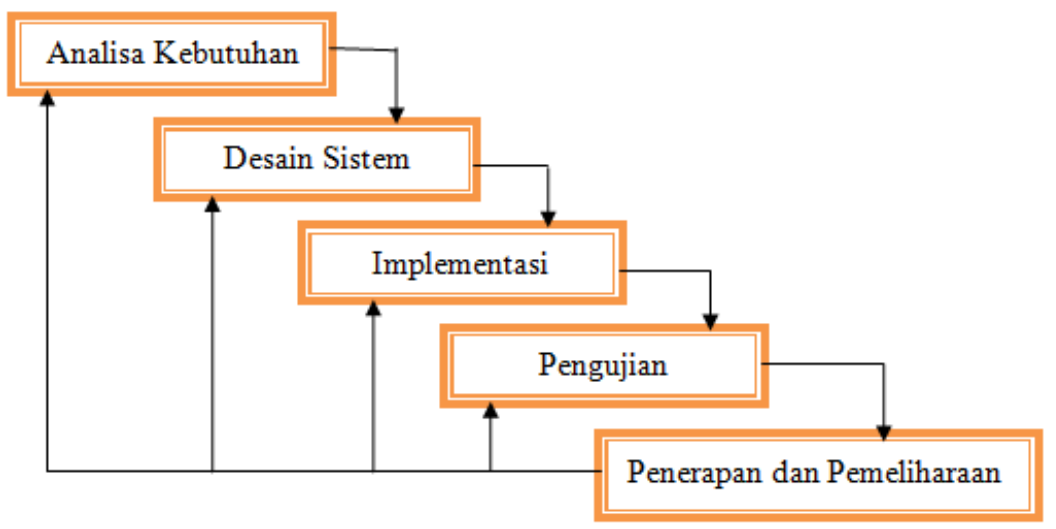

Gambar 1. Bagan Metode Waterfall 
Metode waterfall memiliki 5 tahapan yaitu [5]:

1. Analisa Kebutuhan

Pada tahap awal dilakukan penganalisaan terhadap kebutuhan sistem secara fungsional seperti proses atau fitur yang akan disediakan oleh sistem serta kebutuhan nonfungsional seperti pengaksesan layanan sistem, kendala sistem dan tujuan dalam penggunaan sistem yang kemudian didefinisikan secara rinci.

2. Desain Sistem

Tahap lanjutan dari analisa kebutuhan yang dimana pada tahap ini ditentukan desain sistem, elemen yang terdapat pada sistem, layout, isi dan kombinasi warna yang akan digunakan pada sistem.

3. Pengkodean

Pada tahap ini, perangkat desain diwujudkan sebagai serangkaian program atau unit program.

4. Pengujian Program

Pada tahap ini dilakukan pengujian sistem menggunakan metode blackbox testing. Program digabung dan diuji sebagai sebuah sistem lengkap untuk memastikan apakah sesuai dengan kebutuhan perangkat lunak atau tidak.

5. Penerapan dan Pemeliharaan

Biasanya, tahapan ini merupakan tahapan yang paling panjang. Sistem dipasang dan digunakan secara nyata. Pemeliharaan melibatkan pembetulan kesalahan yang tidak ditemukan pada tahapan-tahapan sebelumnya dan meningkatkan layanan sistem sebagai kebutuhan baru.

\subsection{Metode Pengembangan Sistem}

Metodelogi yang digunakan yaitu Rational Unified Process (RPU) yang merupakan metode rekayasa sistem yang proses pengembangannya secara iteratif. Iteratif yang dimaksud yaitu menyelesaikan masalah kompleks menjadi simple. RUP menggunakan konsep Unified Modelling Language (UML) [6].

\section{HASIL DAN PEMBAHASAN}

\subsection{Analisa Sistem}

Pada penelitian ini dirancang sebuah aplikasi sistem informasi berbasis android yang menyajikan informasi-informasi tempat wisata, tempat penginapan, fitur pemesanan tempat wisata serta lokasi tempat wisata dan penginapan yang ada di Provinsi Sumatera Selatan. Informasi-informasi yang ada disimpan dalam database yang dibangun menggunakan SQLite yang didalamnya terdiri dari beberapa tabel. Database tersebut kemudian akan diakses oleh sistem informasi. Dalam database kita dapat mengisi informasi berupa detail profil, budget yang diperlukan serta lokasi tempat wisata dan penginapan. Dalam membuat atau membangun aplikasi android ini menggunakan software Android Studio 181.5.

Untuk mengetahui informasi letak posisi atau lokasi tempat wisata penginapan ini digunakan layanan Google Maps. Google Maps akan menunjukkan posisi tersebut dengan mengambil data lattitude dan longitude yang sudah ada 
dalam database SQLite yang sudah dibuat. Pada fitur pemesanan tempat wisata melalui QRbarcode, dibuat tampilan layout XML dan pemograman java class pada android studio. Pengguna memasukkan data yang dibutuhkan pada fitur pemesanan kemudian data akan masuk ke database kemudian diakses, maka akan tampil Qrbarcode pada perangkat android pengguna yang dapat discan di tempattempat wisata yang menyediakan fitur tersebut.

\subsection{Tampilan Hasil Program}

\subsubsection{Tampilan Splash Screen}

Tampilan ini adalah tampilan awal saat membuka aplikasi Sumsel Tourism. Lama durasi tampilannya \pm 6 detik, berisi gambar logo Sumsel dan ucapan selamat datang. Tampilannya seperti gambar 2 .

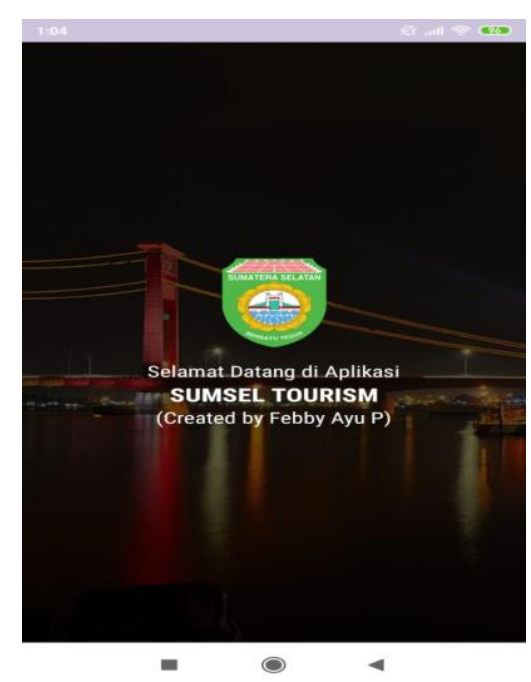

Gambar 2. Tampilan Splash Screen

\subsubsection{Tampilan Menu Utama}

Menu utama yaitu tampilan setelah splash screen. Pada menu ini terdapat 4 simbol tombol, dimulai dari yang paling kiri adalah tombol tempat wisata, tempat penginapan, profile, dan contact yang memiliki fungsi berbeda. Form terlihat pada gambar 3 dan gambar 4 . 
Jurnal Riset Sistem Informasi Dan Teknik Informatika (JURASIK)

Volume (4) Juli 2019, pp 74-81

ISSN: 2527-5771/EISSN: 2549-7839

http://tunasbangsa.ac.id/ejurnal/index.php/jurasik
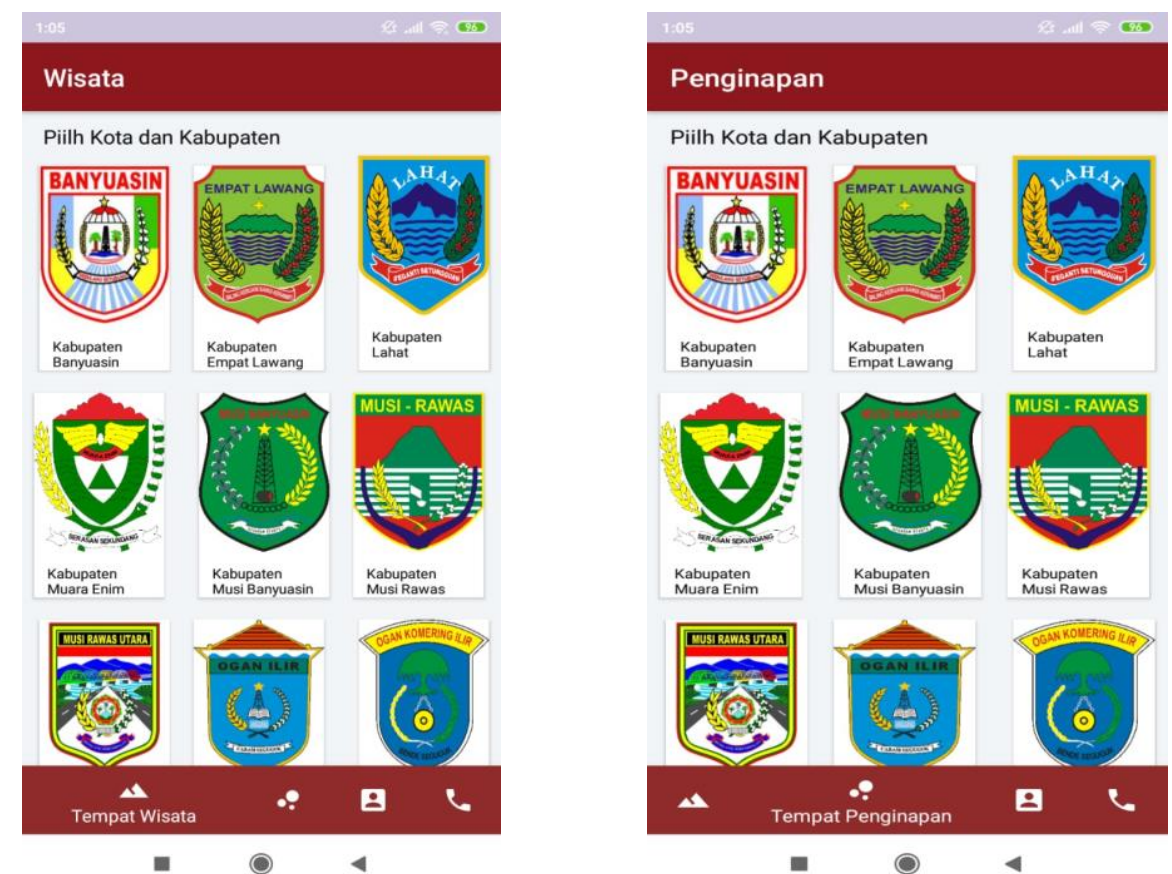

Gambar 3. Tampilan Menu Utama Tempat Wisata dan Tempat Penginapan

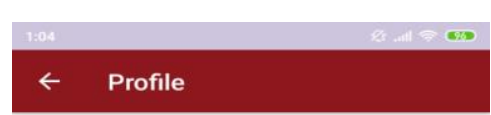

\section{PROFILE SUMATERA SELATAN}

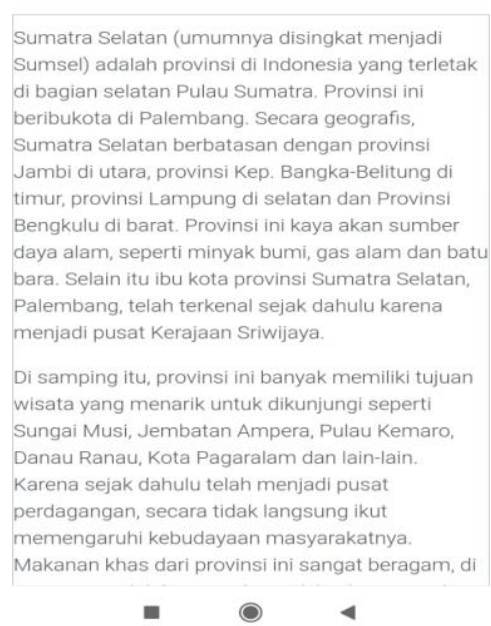

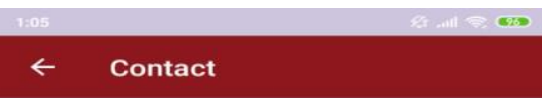

\section{Contact us}

Nomor Telepon :

(0711) $356661-311345$

Email :

tourism-south-sumatra@gmail.com

Alamat

JL. Demang Lebar Daun, Kav. IX, Palembang

Provinsi Sumatera Selatan

Gambar 4. Tampilan Menu Utama Profile dan Contact

\subsubsection{Menu List Tempat}

Pada menu ini akan ditampilkan contoh list tempat wisata dan tempat penginapan pada salah satu kabupaten atau kota yang sudah kita pilih sebelumnya. Formnya ada pada gambar 5 di bawah ini. 

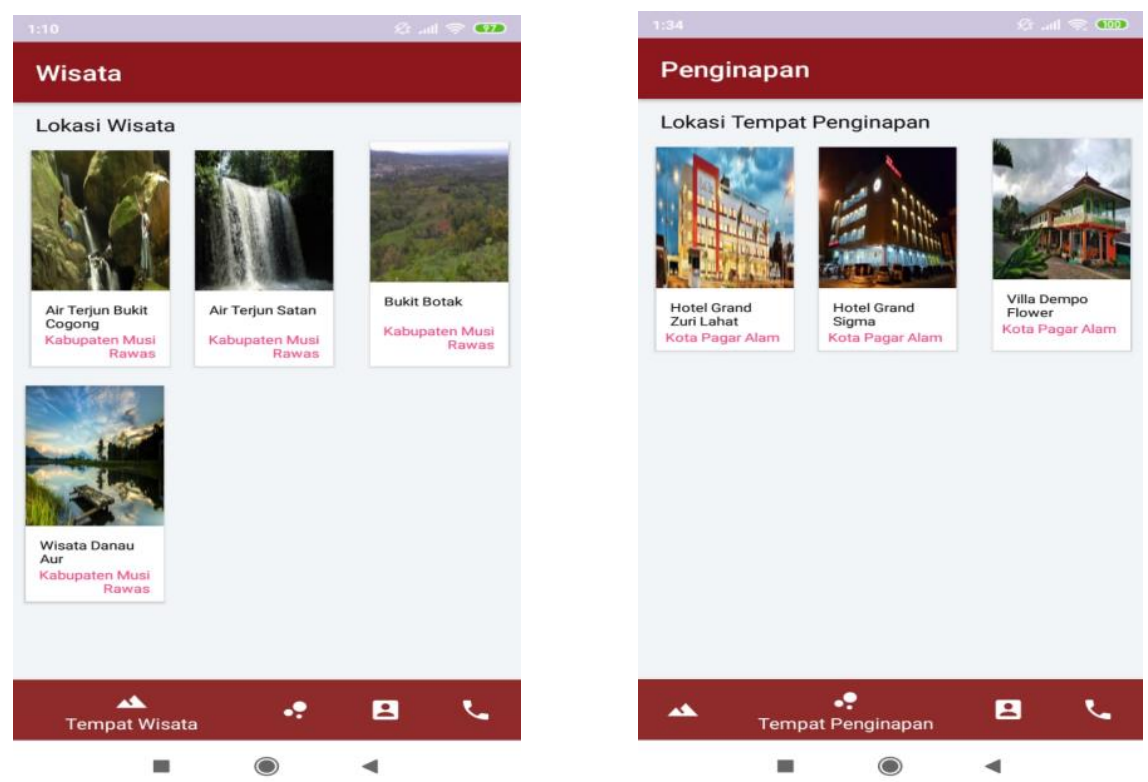

Gambar 5. Tampilan Menu Daftar Tempat Wisata dan Tempat Penginapan di Salah Satu Kabupaten atau Kota

\subsubsection{Kolom Tempat Wisata dan Penginapan}

Aktivitas kolom ini merupakan aktivitas yang muncul ketika memilih salah satu item yang ada pada daftar tempat wisata ataupun tempat penginapan yang terdiri dari deskripsi tempat, foto tempat, rute lokasi melalui google maps, serta pada tempat wisata terdapat fitur boking ticket. Berikut tampilannya pada gambar 6.
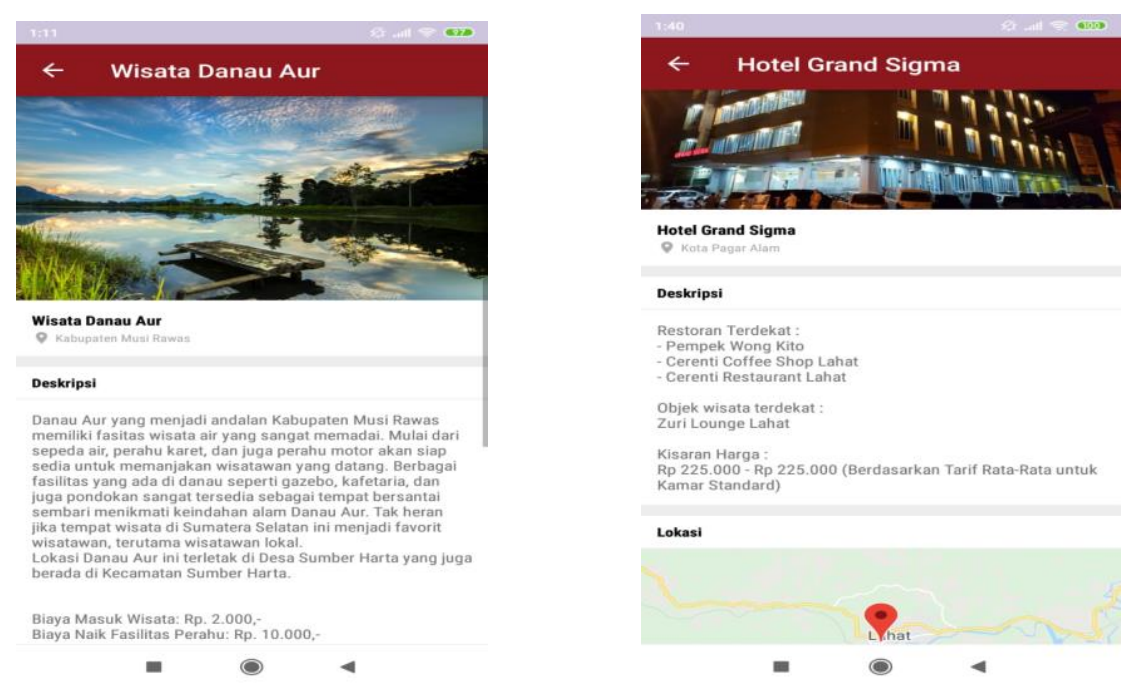

Gambar 6. Tampilan Detail Tempat Wisata dan Tempat penginapan

\subsubsection{Booking Ticket}


Pada form ini terdapat fitur pemesanan tiket tempat wisata, para wisatawan mengisi data No. HP, Jumlah Tiket yang Dipesan, Jam Pemesanan Lokasi kemudian tekan tombol tampilkan QR Code, maka kode QR akan tercetak. Proses yang ada pada gambar 7 .
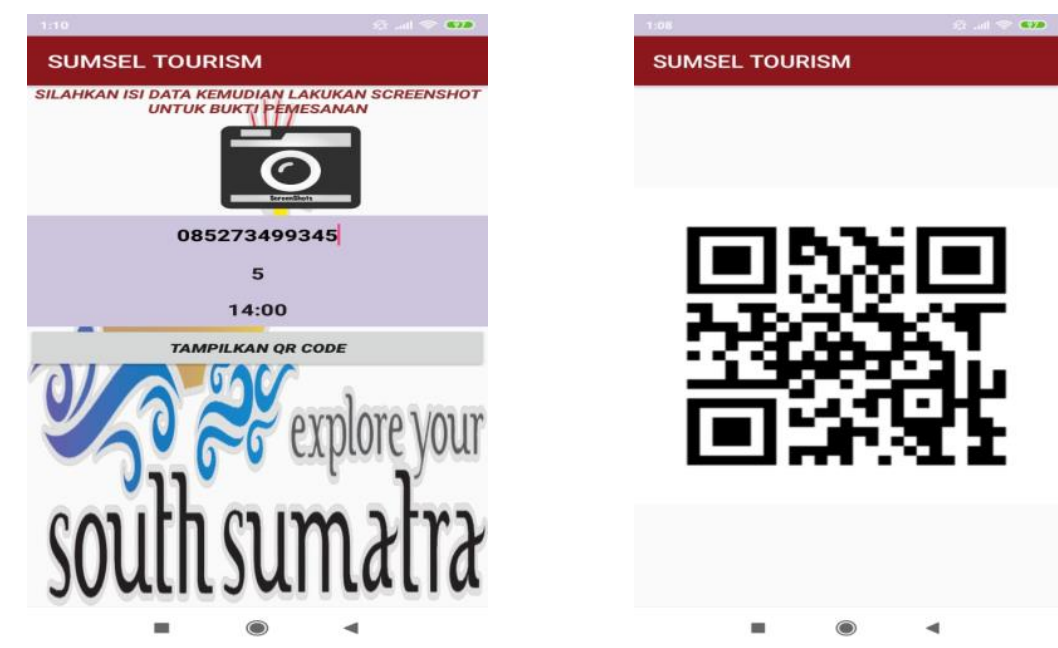

Gambar 7. Tampilan data yang harus diisi saat melakukan pemesanan tiket wisata

\subsubsection{Map}

Pada form ini memiliki fungsi untuk menampilkan map, seperti gambar di bawah ini.

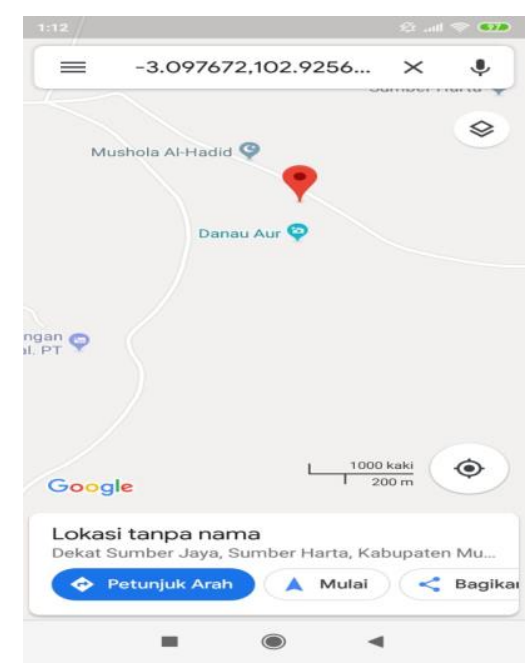

Gambar 8. Tampilan Peta

\subsubsection{Pengujian Fungsional Sistem}

Pengujian setiap halaman atau form tahapan pada aplikasi Sumsel Tourism dilakukan untuk mengetahui kesesuaian antara sistem yang telah dirancang di awal dengan fungsional sistem yang telah dibuat. 
Tabel 1. Hasil Pengujian Fungsional Aplikasi

\begin{tabular}{|c|c|c|c|}
\hline \multirow[t]{2}{*}{ No. } & \multirow[b]{2}{*}{ Halaman yang Diuji } & \multicolumn{2}{|c|}{ Hasil Pengujian } \\
\hline & & Berhasil & Gagal \\
\hline 1. & Splash Screen & $\sqrt{ }$ & - \\
\hline 2. & Menu Utama & $\sqrt{ }$ & - \\
\hline 3. & Menu Utama Tempat Wisata & $\sqrt{ }$ & - \\
\hline 4. & Menu Utama Tempat Penginapan & $\sqrt{ }$ & - \\
\hline 5. & Menu Utama Profile & $\sqrt{ }$ & - \\
\hline 6. & Menu Utama Contact & $\sqrt{ }$ & - \\
\hline 7. & Menu Pilihan Kabupaten dan Kota & $\sqrt{ }$ & - \\
\hline 8. & Menu List Tempat Wisata & $\sqrt{ }$ & - \\
\hline 9. & Menu List Tempat Penginapan & $\sqrt{ }$ & - \\
\hline 10. & Menu Booking Ticket Wisata & $\sqrt{ }$ & - \\
\hline 11. & Menu Tampilan Peta di Google Maps & $\sqrt{ }$ & - \\
\hline
\end{tabular}

\section{SIMPULAN}

Berdasarkan penelitian dan pengujian sistem, dapat diambil beberapa kesimpulan yaitu telah dibangun aplikasi Sistem Informasi berbasis android dengan nama Sumsel Tourism yang memberikan informasi berupa tempat wisata, tempat penginapan berupa deskripsi singkat, budget, foto, rute perjalanan menuju ke lokasi dan terdapat juga fitur pemesenan tiket tempat wisata. Melalui aplikasi yang diakses secara online ini user atau wisatawan menjadi lebih mudah untuk mendapatkan informasi secara cepat dan akurat saat berpariwisata. Metode waterfall sebagai penerapan dalam perancangan aplikasi supaya dapat mempermudah menyelesaikan rancangan aplikasi ini.

\section{DAFTAR PUSTAKA}

[1] Afrina, Mira. 2017. Perancangan Sistem Informasi Pariwisata Berbasis Android. Jurnal Universitas Sriwijaya.

[2] Hutapea, Prilly. 2018. Perkembangan Pariwisata Dilihat dari Jumlah Kunjungan Wisatawan Mancanegara di Provinsi Sumatera Selatan, https://sumsel.bps.go.id/news/2018/05/26/9/perkembangan-pariwisata.html, diakses tanggal 23 November 2018.

[3] Dinas Kebudayaan dan Pariwisata Kota Palembang. 2015. Buku Petunjuk Wisata Kota Palembang. Palembang : Dinas Kebudayaan dan Pariwisata Kota Palembang.

[4] Aliyah, Fie Jannatin. 2014. Sistem Informasi Geografis Berbasis Web Mengenai Penyebaran Fasilitas Pendidikan, Perumahan, dan Rumah Sakit di Bekasi. Jurnal. Universitas Gunadarma.

[5] Sasmito, Ginanjar Wiro. 2017. Penerapan Metode Waterfall Pada Desain Sistem Informasi Geografis Industri Kabupaten Tegal. Jurnal Informatika:Jurnal Pengembangan IT (JPIT) , ISSN: 2477-5126 Vol. 2, No. 1, Januari 2017.

[6] Pressman , Roger S . 2002. Rekayasa Perangkat Lunak Pendekatan Praktisi. Buku 1, Hal 536. 